\title{
KIMBERLITE METASOMATISM AT MUROWA AND SESE PIPES, ZIMBABWE
}

\author{
Chris. B. Smith ${ }^{1}$ K.M. Sims ${ }^{2}$ L. Chimuka ${ }^{2}$, A.D. Beard ${ }^{3}$ and R. Townend ${ }^{4}$ \\ ${ }^{1}$ Consultant to Rio Tinto Mining and Exploration Ltd., United Kingdom; ${ }^{2}$ Rio Tinto Mining and Exploration Ltd., ${ }^{3}$ Birkbeck \\ College, United Kingdom; ${ }^{4}$ Consultant Mineralogist, Western Australia
}

\begin{abstract}
The Cambrian-aged Murowa and Sese kimberlites are located within the Archean Zimbabwe Craton just $\mathrm{N}$ of the boundary with the Limpopo Mobile Zone. The root zones of pipes are exposed at the current erosion level. Kimberlite lithologies present are hypabyssal macrocrystic kimberlite ("HMK"), HMK breccia, tuffisitic kimberlite breccia ("TKB") and minor lithic tuffisitic kimberlite breccia ("LTKB"). Country rocks are Archean $2.6 \mathrm{Ga}$ Chibi and Zimbabwe granite batholiths. Kimberlite metasomatic effects are widespread, and can be laterally as extensive as the kimberlites themselves.
\end{abstract}

The porphyritic granites are composed of fresh Kfeldspar, oligoclase, quartz, biotite and muscovite. During initial metasomatism the granites become spotted with green chlorite, needles of alkaline amphiboles (winchite, riebeckite, arfvedsonite) and pyroxenes (aegirine-augite) with minor carbonate and felts of talc. Plagioclase becomes extensively altered, dusted and reddened with hematite, whereas K- feldspar remains unaffected. The granites become converted to syenite through removal of quartz. Similar fenitisation has been recorded at Toubabouko lamproite (Ivory Coast) (Knopf, 1970), Lesueur Township kimberlite in Quebec (Watson, 1973), Bow Hill ultramafic lamprophyre dyke (Jaques et al., 1986) and adjacent to the Lissadell Road lamproite dykes, Western Australia (C.B. Smith, unpublished data).

As metasomatism intensifies at Murowa and Sese, veins of green metasomatite cut and disrupt the granite. Progressive disruption entrains granite blocks, breaking down the granite still further and transporting needlelike feldspar slivers, so giving rise to LTKB.

The metasomatite chemistry is intermediate between granite and kimberlite, having lower $\mathrm{Si}, \mathrm{Al}$ and $\mathrm{Y}$ than granite, similar amounts of $\mathrm{K}, \mathrm{Na}, \mathrm{Ti}$ and $\mathrm{Ba}$, higher $\mathrm{Ca}, \mathrm{Mg}, \mathrm{Ni}, \mathrm{Cr}, \mathrm{Nb}, \mathrm{Sr}, \mathrm{P}, \mathrm{CO}_{2}, \mathrm{H}_{2} \mathrm{O}^{+}$and a higher $\mathrm{Fe}^{3+} / \mathrm{Fe}^{2+}$ ratio. Ferguson et al. (1973) described similar chemical alteration of wall rock adjacent to De Beers kimberlite pipe, South Africa

The metasomatic process is analogous to the fenitisation of granitic wall rock by carbonatite. Kimberlite metasomatism at Murowa and Sese appears to be formed by fluids from the rising but pent-up proto-kimberlite melt penetrating into cracks and the matrix of the granite country rock and reacting with it. These fluids are alkaline, hydrous and $\mathrm{CO}_{2}$-rich, perhaps with affinities to the alkaline carbonates erupted from the Oldoinyo Lengai carbonatite volcano.

\section{INTRODUCTION}

Metasomatism accompanying kimberlite emplacement is a world-wide phenomenon. The effects are usually weak, consisting of "ground preparation" fracturing accompanied by hydrothermal metasomatism. This often leads to slight induration of country rock adjacent to kimberlite and to minor green staining. At the Murowa and Sese Pipes in southern central Zimbabwe, the metasomatism is quite extensive and well exposed and the processes can be readily studied. The results described here were obtained by Rio Tinto during the 1996-2000 diamond exploration programme that discovered and evaluated the kimberlites.

\section{LOCATION AND GEOLOGICAL RELATIONSHIPS}

The Cambrian-aged Murowa and Sese kimberlites lie within the Archaean Zimbabwe Craton just $\mathrm{N}$ of the boundary with the Limpopo Mobile Zone (Fig. 1). Country rock is late Archean, consisting of the Chibi and Zimbabwe granite batholiths (Robertson, 1974), part of the $\sim 2.6 \mathrm{Ba}$ Chilimanzi suite of granites. These granites intrude older Archean Shabani tonalitic gneiss complex and greenstones of age 2.6-3.5 Ba.

The granitic country rock is leucocratic, hypidiomorphic inequigranular, slightly porphyritic in places, of adamellite to granite composition with roughly equal quantities of quartz, oligoclase and kfeldspar (microcline), minor biotite and muscovite, and 
accessory clinozoisite, zircon, apatite and opaques. of K-rich metasomatism different in style to that of the Unfenitised granite is quite Na-rich fenite.

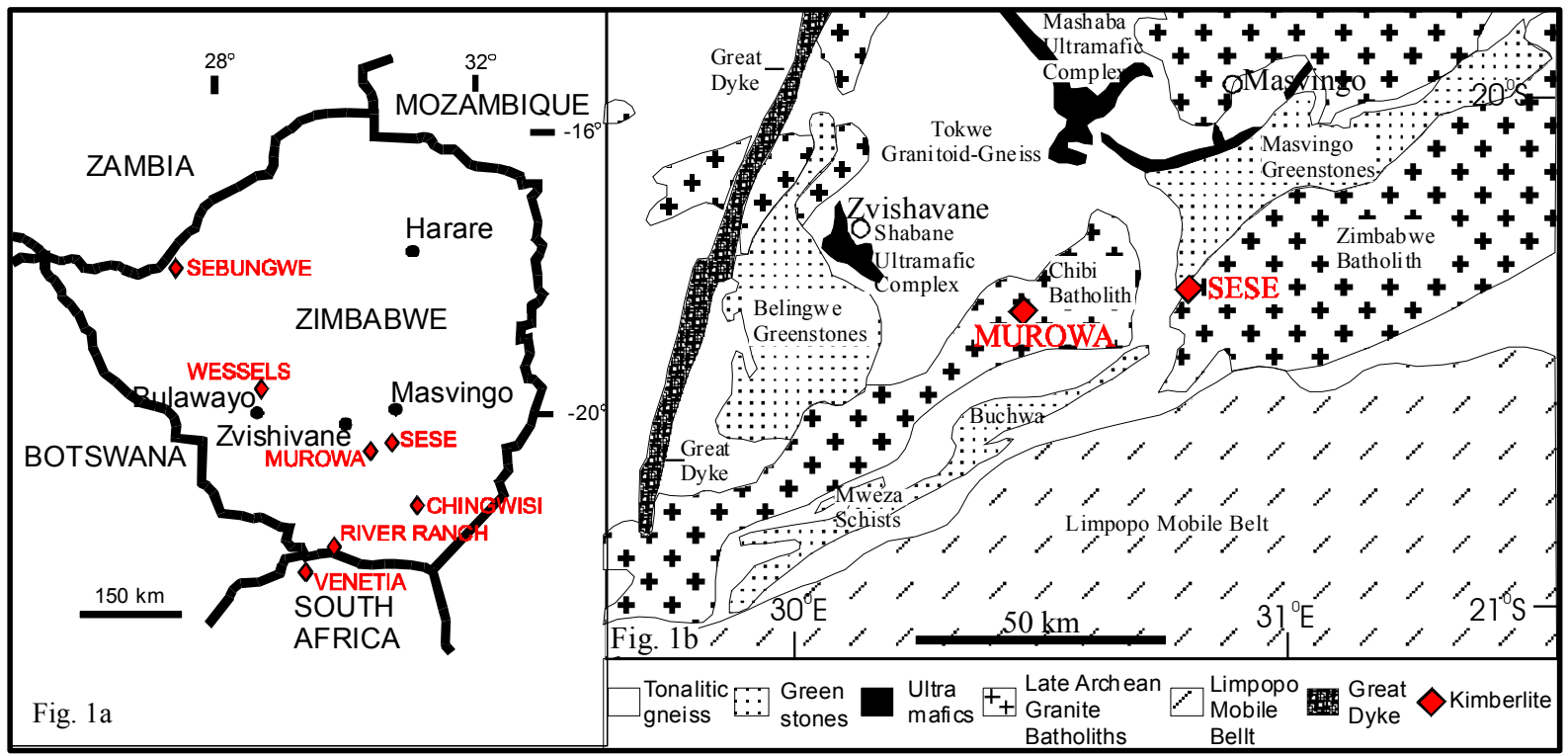

Figure 1: Location of Murowa and Sese kimberlites.

fresh, apart from slight sericite formation in plagioclase and chlorite in biotite.

The pipe root zones are exposed at the current erosion level, with complicated multi-lobed outlines characteristic of the basal part of pipe development. Narrow vertical dykes and shallow-dipping sills also occur. Kimberlite lithologies present are HMK, HMKB, TKB and LTKB using terminology of Clement and Skinner (1985). HMK occur as dykes, sills, as pipe infill, and as matrix to HMKB. It carries abundant rounded, fresh to serpentinised olivine macrocrysts. Some micaceous dykes have phlogopite as the dominant groundmass mineral, together with subhedral olivines, set in a poikilitic calcite cement interpreted to be of primary origin. The groundmass of mica-poor dykes has a mosaic of calcite with occasional segregations of coarse monomineralic carbonate containing inclusions of apatite.

HMKB forms irregular cores to several pipes. It contains accidental xenoliths of angular to subrounded syenitic (fenitised granite), clasts of earlier-formed HMK, and occasional well rounded mantle peridotites. Xenoliths have "ghosted", embayed outlines, and show extensive alteration reaction rims developed through partial digestion by kimberlite matrix. Mantle peridotites are infiltrated by narrow veins of a tetraferriphlogopite-talc-carbonate assemblage, a form
Highly altered breccia, interpreted as TKB, occurs locally in proximity to wall rock, often grading via LTKB into in-situ fenitised wall rock breccia. The TKB contains high proportions of granite xenoliths, rounded olivine macrocrysts and microcrysts now completely altered to talc surrounded by secondary fibrous pyroxenes and amphiboles, and occasional rounded xenoliths of earlier-formed micaceous HMK. Spherical lapilli are characteristically present, sometimes formed around a kernel of olivine. The TKB matrix is predominately blue-green soda amphibole, sometimes displaying a spherulitic texture.

\section{FEATURES OF METASOMATISM}

The kimberlite pipes, sills and dykes all show extensive metasomatism of adjacent wall rock. The metasomatism can be laterally as extensive as the kimberlites themselves, up to $100 \mathrm{~m}$ wide.

Furthest from the pipe the fenitisation of granite is marked macroscopically by reddening of plagioclase feldspar and development of blue-green spots and veins (Fig. 2). The blue-green patches are composed of chlorite, needles of winchite, riebeckite, magnesioarfvedsonite, and aegirine-augite, sometimes in association with minor carbonate and felts of talc.

The fenitisation results in the breakdown of quartz, the replacement of biotite by pyroxenes and amphiboles; and granite becomes converted into syenite. The K- 
feldspar (microcline) remains clear, chemically unchanged, and poikilitic to the plagioclase, but the latter becomes sericitised and reddened by development of iron oxide dust (Fig. 2).

Closer to the pipe the veining becomes stronger and thicker and the fenite takes on the appearance of an insitu breccia, without any rotation or transport of clasts. Veins are principally of carbonate but are bordered by the acicular alkaline pyroxenes and amphiboles. In places the mafic minerals become dominant and develop a spherulitic habit, as described also for the

TKB above. Rare rounded shapes reminiscent of olivine suggest some kimberlitic material may have been injected.

Breccias show signs of mobilisation, displacement and transportation of syenite clasts within the host carbonate-chlorite-alkaline amphibole-pyroxene matrix (Fig. 2). A variety of LTKB, frequently seen at kimberlite contacts, has flow-aligned matchstick-like slivers of entrained feldspar. The fenitised wall rock and LTKB contain nil, or next to nil, kimberlite component. However, the distinction between LTKB and TKB at Murowa and Sese is not sharp or clear cut; being based on the incoming of recognisable xenoliths of micaceous HMK and altered olivine macrocrysts in significant quantities.

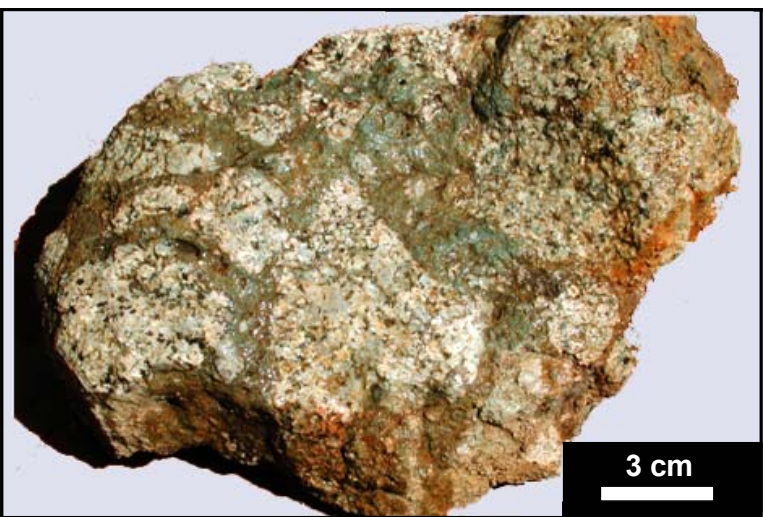

Figure 2: Murowa Pipe K1 surface outcrop sample. Breccia of disoriented blocks of green-spotted. desilicified, fenitised granite (syenite) set in a matrix of green metasomatite.

\section{CHEMISTRY OF THE METASOMATITE}

Compared to granite country rock, the fenites have lower $\mathrm{Si}, \mathrm{Al}$ and $\mathrm{Y}$, similar amounts of $\mathrm{K}$, Ti and $\mathrm{Ba}$, higher $\mathrm{Ca}, \mathrm{Mg}, \mathrm{Ni}, \mathrm{Cr}, \mathrm{Nb}, \mathrm{Sr}, \mathrm{P}, \mathrm{CO}_{2}, \mathrm{H}_{2} \mathrm{O}^{+}$and a higher $\mathrm{Fe}^{3+} / \mathrm{Fe}^{2+}$ ratio (Figs. 3, 4).
The fenites were divided into five categories for analysis, according to the visual amount of green spotting or brecciation which in general correlates with the degree of chemical alteration of the granite host. The chemical composition of the fenites is intermediate between granite and kimberlite pointing to the close association between the metasomatising fluids and kimberlite. There is a general progression in chemistry from fenite via TKB with its matrix rich in alkali amphiboles and pyroxenes, to HMKB and HMK.

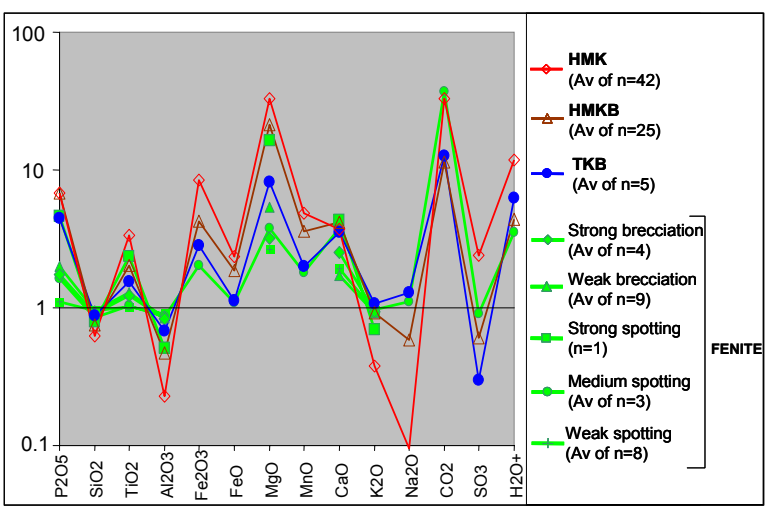

Figure 3: Murowa kimberlite and fenite major element chemistry, normalized to average Chibi granite $=1$.

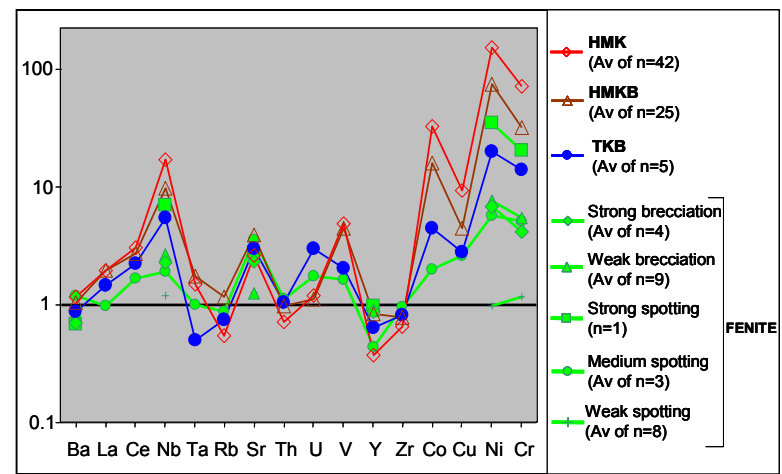

Figure 4: Murowa kimberlite and fenite trace element chemistry, normalized to average Chibi granite $=1$.

\section{COMPARISONS WITH KIMBERLITE AND LAMPROITE METASOMATISM WORLD-WIDE}

In general it is emphasised that kimberlites do not cause extensive thermal metamorphism of adjacent country rock (Wagner, 1914). Dawson and Hawthorne (1970) describe green staining and induration of shales and sandstones, without recrystallisation. The process is common to both kimberlites, lamproites and other 
lamprophyres, and similar effects can be seen elsewhere with granitic country rock, e.g. Bow Hill ultramafic lamprophyre, Western Australia (Jaques et al., 1986).

Ferguson et al. (1973) make distinctions between high level and low level activity within the crust, with loss of volatiles by near-surface degassing causing rapid crystallisation and leaving only a hydrous $\mathrm{CO}_{2}$-rich phase left to penetrate wall rocks. At deeper levels with slower release of contained volatiles they record $\mathrm{K}$ and $\mathrm{P}$ as additional metasomatising fluid components.

Massive outcrops of indurated, disturbed, sandstone wall rocks occur adjacent to lamproite volcanoes at Kapamba (Scott Smith et al., 1989), West Kimberley (Jaques et al., 1986), and Prairie Creek (Miser and Ross, 1923). This disturbance seems likely to have occurred during initial explosive, gas-rich breakthrough to surface; the fractures developed providing pathways for fluid escape and hydrothermal alteration, with introduction of veinlets of silica, barite, and green staining. The bright green staining of "McKeown's Breccia" at the basal contact of the Mwadui kimberlite crater has been ascribed to hydrothermal alteration of brecciated country rock granite-gneiss (Dawson, 1980). The above features parallel the fracturing of country rock granite and injection of veins of hydrothermal products at Murowa.

Clement (1982) describes the nature of contact breccias found as pendants to roofs of blind dome-like pipe offshoots and country rock overhangs in the root zones of deeply mined pipes near Kimberley. These breccias contain locally derived, angular fragments of country rock, often without any kimberlite matrix. He ascribes their origin to shattering of wall rock by pressure of gas/fluid exsolved from rising kimberlite. The LTKB breccias found near the kimberlite/granite contacts at Murowa and Sese have many features in common with the contact breccias of Clement (1982).

Ferguson et al. (1973) describe deeper level fenitisation of granitic wall rock adjacent to De Beers Pipe at Kimberley. As at Murowa, feldspars are altered and replaced by white mica and mafic minerals altered to green chlorite. Introduction of alkali amphiboles and pyroxenes into fenitised granite at Murowa and Sese has its parallels in the $1 \mathrm{~m}$ wide fenitisation of granite country rock by the Toubabouko (Ivory Coast) lamproite dyke (Knopf, 1970) with development of a syenitic microcline-arfvedsonite assemblage. At Lesueur Township in Quebec riebeckite is developed at the contact with calcite-rich kimberlite (Watson, 1973), whilst chlorite, magnesio-arfvedsonite and reddened K- feldspar is found within the $1 \mathrm{~m}$-wide zone of fenitised granite adjacent to the Bow Hill ultramafic lamprophyre dyke (Jaques et al., 1986) and in similar metasomatised granite adjacent to the Lissadell Road lamproite dykes, Western Australia.

Ferguson et al. (1973) undertook chemical analyses of granite wall rock adjacent to the De Beers pipe. In common with Murowa, they record increases during fenitisation in $\mathrm{Mg}, \mathrm{Ca}, \mathrm{Sr}, \mathrm{CO}_{2}, \mathrm{P}, \mathrm{H}_{2} \mathrm{O}^{+}$, and $\mathrm{Fe}^{3+} / \mathrm{Fe}^{2+}$, and decreases in $\mathrm{Si}$. They conclude that the metasomatising fluids were therefore $\mathrm{CO}_{2}$ and $\mathrm{H}_{2} \mathrm{O}^{+}$rich and oxidising.

\section{COMPARISONS WITH CARBONATITE FENITISATION}

Metasomatism at Murowa and Sese has parallels with the fenitisation of granitic wall rock that accompanies carbonatite emplacement, although with carbonatites it is typically potash feldspar that suffers alteration not plagioclase. Carbonatite metasomatism is often on a much larger scale than with kimberlites, and leads via desilicification to extensive development of outer rings of syenite surrounding an inner carbonatite core. Alkali pyroxenes and amphiboles are common mafic minerals in the fenites, and the chemical changes accompanying fenitisation parallel those at Murowa and Sese.

\section{DISCUSSION AND CONCLUSIONS}

The metasomatic process at Murowa and Sese is analogous to the fenitisation of granitic wall rock that accompanies carbonatite emplacement. Similar metasomatic effects have occasionally been recorded from kimberlite and lamproite contacts around the world and are probably more common than is generally realised. Kimberlite metasomatism appears to form from fluids from rising but pent-up proto-kimberlite melt penetrating into cracks and matrix of the granite country rock and reacting with it. These fluids are hydrous, alkaline, and $\mathrm{CO}_{2}$-rich, perhaps similar to alkaline carbonates erupted from the Oldoinyo Lengai carbonatite volcano, certainly analogous to metasomatising agents associated with fenitisation of wall rocks by carbonatites.

\section{ACKNOWLEDGEMENTS}

Rio Tinto Zimbabwe Ltd. and Rio Tinto Mining and Exploration Ltd. are thanked for kind permission to publish data resulting from their diamond exploration 
and pipe evaluation activities. Many geological colleagues in Zimbabwe contributed to the findings, and the contributions of Kevin Fox, Frieder Reichardt, Adam Duffin, Strength Mkonto and Richard Walkland are especially acknowledged.

\section{REFERENCES}

Clement, C.R., 1982. A comparative geological study of some major kimberlite pipes in the Northern Cape and Orange Free State. Ph.D. Thesis (2 vols.), University of Cape Town.

Clement, C.R., Skinner, E.M.W., 1985. A textural-genetic classification of kimberlites. Trans. Geol. Soc. South Africa, 88, Part 2, 403-409.

Dawson, J.B., 1980. Kimberlites and their xenoliths. Springer Verlag, Berlin.

Dawson, J.B., Hawthorne, J.B., 1970. Intrusion features of some hypabyssal South African kimberlites. Bull. Volcanol. 34, pp.740-757.

Ferguson J., Danchin R.V., Nixon P.H., 1973. Fenitization associated with kimberlite magmas. In: P.H. Nixon (Ed.), Lesotho Kimberlites, Lesotho National Development Corp., Maseru, pp. 207-213.

Jaques, A.L, Lewis, J.D., Smith, C.B., 1986. The kimberlites and lamproites of Western Australia. Geol. Surv. Western Australia, Bull. 132.

Knopf, D., 1970. Les Kimberlites et les roches apparentees de Cote D'Ivoire. Sodemi, Abidjan.

Miser, H.D., Ross, C.R., 1923. Diamond-bearing peridotite in Pike County, Arkansas. USGS, Bull 735-I, 279-322

Robertson, I.D., 1974. Explanation of the geological map of the country south of Chibi. Geological Survey of Zimbabwe, Short Report No. 41.

Scott Smith, B.H., Skinner, E.M.W., Loney, P.E., 1989. The Kapamba lamproites of the Luangwa Valley, Eastern Zambia. In Ross, J. (Ed.), Kimberlites and Related Rocks, Vol. 1, Their Composition, Occurrence, Origin and Emplacement. Proc. Fourth International Kimberlite Conference, Perth, Geological Society of Australia Spec. Pub. No. 14, pp. 189-205.

Wagner, P.A., 1914. The diamond fields of Southern Africa. C. Struik Pty Ltd., Capetown, 1971.

Watson, K.D, 1973. Kimberlites of the Superior Province, Canadian Shield. Extended Abstracts, Int. Kimberlite Conference, Cape Town, pp. 305-308.

Contact: CB Smith, 10 Upper Camden Place, Bath BA15HX,

United Kingdom, E-mail: chris b_smith@hotmail.com 